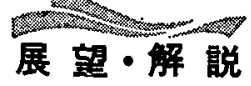

\title{
アモルファス状態における原子と電子の動きの可視化*
}

\author{
一一古典的な分子動力学法と量子力学的分子動力学法一-
}

米沢富美子**，坂本昇一***

\section{Visualization of Atomic and Electronic Movements in Amorphous States}

Classical and Quantum-Mechanical Molecular Dynamics-

Fumiko Yonezawa and Shoichi Sakamoto

アルモファス系の研究に扎いて コンピュータ 一・シミュレーションが非常に大きな寄与をして いること,さらに，そこから得られた結果の解析 に和いて，コンピューター・グラフィックスがこ の上もなく重要な役割を果たしていることを，い くつかの例を通して解説する。具体的には，ま ず，古典的な分子動力学法を使って，アモルファ ス構造の本質を解明し, 次に, 量子力学的な分子 動力学法を使って電子の動さを追い, アモルファ ス物質にお活る原子構造と電子分布の関係を明ら かにする。

\section{1.はしめに}

凝縮系の物理学の分野では，非結晶物質の研究 は結晶の研究に比べてずっと遅れている。結晶に ついてい光ば，X線回折による結晶構造の解析が 提案されたのは1910年代であり，その後今日K至 るまで，結晶構造は詳細に調べられている。ま た，1920年代に量子力学が確立された後，1930年 代には，早々と結晶の電子状態の基礎が築かれ た。をこでは，ブロッホの定理に代表されるさま ざまの理論が量子力学にのっとって展開された。

これらの実験的研究，または，理論的表式にお いては，結晶構造が周期性をもつこと，換言する と，並進対称性をもつことが，フルに利用されて

\footnotetext{
*原稿受付 1991 年12月 4 日

**慶応義熟大学理工学部

***成蹊大学工学部
}

Wっ。

しかし，凝縮系の仲間には，結晶でない物筫が 結晶よりも多く存在している。非結晶固体や液体 がその例である。これらの物質は，原子構造が並 進対称性を持たないことが共通点であり，原子配 置のこの性質は，「非結晶」「非周期」「不規則」 「ランダム」「アモルファス」「ガラス」等，さぬ ざまな表現で記述されるが，これらの表現はほぼ 同じ意味で使和れている。本稿でも，これらの言 葉を同義語的に使うことにする。

アモルファス棈造に関して丰験から得られる情 報のなかで，結晶の周期性（あるいは亚進対称性） は，片鱗も残っていないことと，各原子の近傍の 局所的な配置は結晶に和けるものと変わらないこ との 2 点が，最も重要なものである。，前者は，長 距離秩序の欠如と呼ばれ，徭者は，短距離秩序の 存在と呼ばれている。この 2 点はすべてのアモル ファス構造に共通のものであるが，それ以上の詳 細は央験からは直接には得られない。この事情 は, 将来笑験装置が大幅に進歩してる変わらな w。

こらいら状況を考虑すると, コンピューター・ シミュレーション, なかであ, 分子動力学法 (Molecular Dynamics 法一略して, MD法と 呼ぶ）が一番威力を発揮するのは，不規則系の研 究においてで方ことは，容易に想像がつく。夹 際, 分子動少学法が導入された1950年代以降，M 
D法の対象として研究されたのは，ほとんどが不 規則系であった。

本稿では，MD法コンピューター・シミュレー ションによって，不規則系の中の原子や電子に関 してどのよらな情報が得られているのかを紹介す る。第 2 節では，古典的な MD法を使って，ガラ ス転移の様子，および，アモルファス構造の特徽 を調べる。特に，アモルファス棈造を安定にする 原子の並び方とはどんなものであるのかを明らか にする。第 3 節では, 量子力学的 MD (QMD) 法 を使って，アモルファス・シリコンの物性を研究 するための方針を述べ，第 4 節では，得られる物 性を電子分布との関連で議論する。これらの結果 はいずれる，コンピューター・グラフィックスを 使って可視化し, 解析に利用する。第 5 節に関連 の情報を記す。

\section{2. ガラス転移}

分子動力学法というのは, 系を構成する多数の 粒子（分子であったり原子であったりする）のお のおのに対するニュートン運動力程式を解くこと によって, 粒子の運動の時間発展を求め, 系の諸 物性を導く方法である。構成粒子の数名 $N$ 個ある 場合には，N個の連立微分方程式を解くことにな る。実際に, コンピューターで扱う際には, 微分 方程式を差分方程式に置き換える。

それぞれの系を特徽づけるのは, 粒子間ポテン シャルである。ここでは，粒子間にレナード・ジ ョーンズ型の対ポテンシャルが働く系に対する

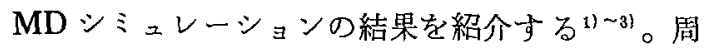
期境界条件を採用し，粒子の数は 864 個で，積分 の時間ステップは $0.5 \times 10^{-14}$ sである。

この MD法で, われわれはアモルファス構造が 液体からガラス転移を経て作成される様子を詳細 に調ベ，系の中の原子の動きをコンピューター・・ グラフィックスを使って映像化し，その様子を映 画にした。可視化を通してガラス転移、アモルフ アス構造などに関する多くの知見を得ることがで きた。

特に，ガラスを作成する時の冷却速度の違いに よって，ガラスの安定性がどのように変わってく るかを調べ，その結果を解析することによって，
アモルファス構造を安定化するミクロな原子配置 の特徵を明らかにした。

ガラス転移以下の温度でガラスをアニールする と，非常に速い冷却速度 $\left(10^{13} \mathrm{~K} / \mathrm{s}\right)$ で作成した ガラスは結晶化するのに対して，急冷ではあるが 上述のものよりは遅い冷却速度 $\left(10^{11} \mathrm{~K} / \mathrm{s}\right)$ で作 成したガラスは安定で, 相当長い時間の後にもア モルファス構造を保持していることが分かった。

この結果はつぎのように説明される。冷却速度 が著しく速い場合には，できるだけ低いエネルギ 一の構造を選ぶために，アトムたらが並び換えを する時間が匡とんどないので，広い範柬の原子の 再配列は実現せず，各原子のごく近傍だけの並び 換党が行われる。したがって，多くの二十面体構 造が系の中に作られる。

この超急冷の過程で作られる二十面体構造は， 図 1(a)に示されるような形をして招り，中心の原 子を囲む最隣接原子12個が一重の㲄をなしてい る。このクラスターには最隣接原子をむすぶボン ドが42本める。図 1 (b)特よび(c)には，比較のため に, 他の13原子クラスター（具体的には, 面心立 万 (fcc) クラスターと六法稠密 (hcp) クラスタ 一）が描かれている。これらのクラスターのボン ドの数は36である。一般に詨ポテンシャルでは, ボンドが 1 本あるごとにエネルギーが得をするの で，ボンドの数が多い经どクラスターのエネルギ 一は低くなる。これが, 球対照的なポテンシャル をもつ原子からなるアモルファス構造の中に，二 十面体的な局所刘称性が多く現れる理由である。
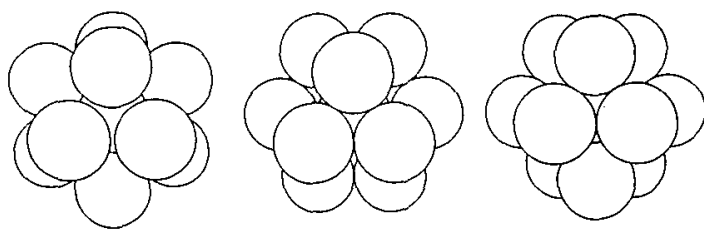

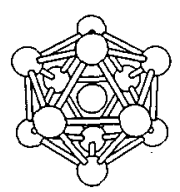

(a)

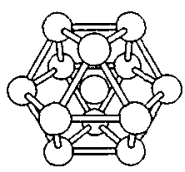

(b)

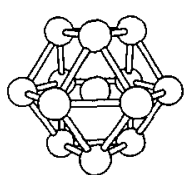

(c)
图1中心の原子を12個の原子が囲んでいるクラスター（括弧 内の数字はクラスター内の最隣接ボンドの数) : (a) 二十 面体的クラスター (42); (b) 面心立方 (fcc) クラスター (36)；(c) 六方稑密 (hcp) クラスター(36). 
超急冷によって作成されたアモルフアス構造の なかには図 1 (a)のような二十面体クラスターが多 く現れるが，上にも述べたようにとれぞれの局所 構造の広がりは小さいので, アニールの過程にお いて，比較的簡単飞結晶クラスターに組み込まれ てしまう。

一方, 冷却速度が，速いけれども上述のものよ り低いという場合には，アトムたちは並び換えの ために多少は長い時間を費やすことができるの で，最隣接より少し遠い所までを含めた再配列が 可能になる。その結果, 図 1 (a)のような一重殻の 二十面体構造より大きくて，から二十面体対称性 をもつクラスターが誕生し得る。そのようなクラ スターの候補として，図2(a) に描かれたようなも のが考えられる。このクラスターには，55個の原 子があり，ボンドの数は234である。やはり, 55個 の原子からなる fcc クラスターが図2(b)に示され て拈り，ボンドの数は 216 である。したがって， この二重クラスターの場合も，二十面体対称性を
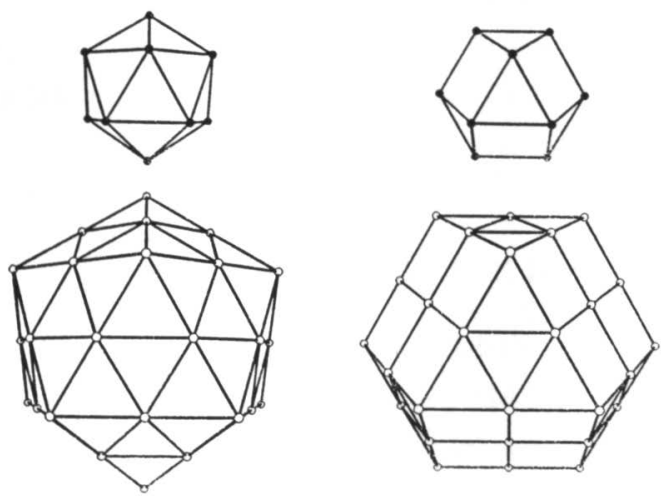

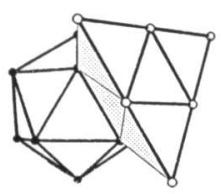

(a)

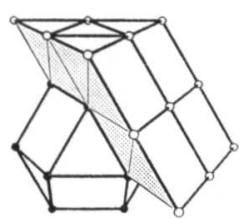

(b)
図 2 (a)二重の殼を持つ二十面体的クラスターの説明図（55 原 子から成り，234の最隣接ボンドをもつ）:(上) 中心の原 子が，(第一殼に属する）12個の原子に囲まれている； （中）第二殼に属する 42 個の原子；(下）第一殼の原子と 第二殼の原子との相対的な位置関係 (b) 二重の殼を持つ fcc 的クラスターの説明図 (55原子から成り, 216の最隣 接ボンドをるつ)：(上)中心の原子が（第一殼に属する） 12個の原子に囲まれている；(中）第二凯に属する42個の 原子；(下) 第一殼の原子と第二殼の原子との相対的な位 置関係

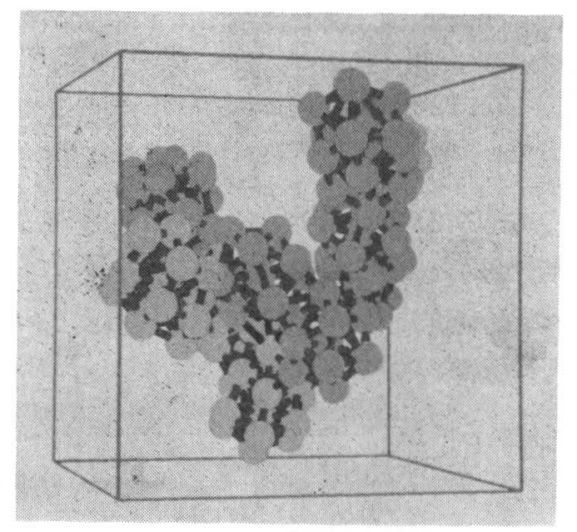

図 3 二十面体的対称性をもつ原子 (黒い原子) のク ラスターと fcc 的対称性をむつ原子(扊色の原 子)のクラスターとが, 互いに入り組んだ構造で 共存していて, 系全体の結晶化を妨け゚ている

もつクラスターの方が低いエネルギーをもつこと が分かる。

実際に，急冷ではあるが比較的低い冷却速度で 作成されたアモルファス構造の中には，この種類 のクラスターが含まれており, 空間的に広がった コヒーレンスをもっているので，構造として安定 である。もらひとつ大事なポイントは, この二重 殼の二十面体クラスターでは，第一殼の原子と第 二款の原子との相対的な位置関係は f f c 結晶的に なっており，まわりの結晶クラスターと共存しや すい形になっていることである。そのため,これ らの二重殼の二十面体クラスターはアモルファス 構造を安定に保つことが理解でさる。具体的に は, 図3で示されるよらな状況が実現して, アモ ルファス構造は安定に保たれる。

\section{3. 第一原理分子動力学法による $\mathbf{a}-\mathrm{SiH}$ の研究}

第一原理分子動力学法といらのは, MD の対象 として, 古典力学的な原子に加えて, 量子力学的 な粒子である電子も考虑するもので，そのための 効率的な方法が最近, カーとパリネロによって提 案された4)。前節で紹介したよらな従来の MD 法 では，原子間ポテンシャルの形を何らかの物理的 な根拠に基づいて仮定する必要があったが，第一 原理 MDでは電子の分布もセルフコンシステン トに求める筋書きになっているので，原子間のポ テンシャルもシミュレーションの一環として道出 することができるのである。 
ここでは，この方法を使って，水索化アモルフ アス・シリュン $(\mathrm{a}-\mathrm{SiH})$ のステブラー・ロンス キー効果に括ける光誘起欠陥生成のミクロな機構 を研究する。

太陽電池梳21世紀のエネ゙ルギー問題を救う夢の デバイスといわれて和り，a-SiH がいま最も広く 使われている。しかし，1975年以前は，a-Siの 光電変換効率は著しく低く，太隄電池の夷用化は 問題外であった。変換効率が低い原因は主とし て, a-Si 中に多数存在するダングリング・ボン ドの作るギャップ準位に起国していた。

1975年に, $\mathrm{SiH}_{4}$ のプラズマ分解による の作成法が導入され，a-SiH は太陽電池のデバイ スとして現実的なものになった。この方法による 作成の際には，多数の水素原子が存在し，これら の水素原子がダングリング・ボンドを満たして, ギャップ準位が消えてしまらために，変換效率が 大幅に改善されたのである。ここでは，水素が救 世主であった。

ところが，この作成法で作られた a-SiH 括い ては, 強度の光照射の後, 光伝導度も暗伝導度も ともに2〜3桁減少することを，1977年に，ステ ブラーとロンスキーか゚見つけた。その際, 欠陷 （主としてダングリング・ボンド）が増加するこ ともその後, 確かめられた。この過程は, $150^{\circ} \mathrm{C}$ での温度アニールによって，完全に元にもどるこ とも確認された。この效果をステブラー・ロンス キ-(SW) 效果と呼ぶ5)。

a-SiH の中では, 水素は $\mathrm{Si}-\mathrm{H}$ の形でのみ存 在することが，実験から分かっている。したがっ て，光誘起欠陷生成の機構としては，フォトンが $\mathrm{Si}-\mathrm{H}$ ボンドを切ってダングリング・ボンドを作 り，水素の方は拡散していって，弱いSi-Si ボン ドを切り，さらにダングリング・ボンドを增やす といらシナリオが実験から示唆されている。生成 されたダングリング・ボンド注当然，変換効率を 下げるわけだから，この意味では，水素はトラブ ルの種であると考えられる。

実際にどういら機構で光出化が起こっているの が解明することは，太陽電池の效率安定といら 見地からも急枒である。

SW 効果の素過程は局所的なものであり, 全系
の原子構造の詳細にはよらないと考えられるの でわれわれの MDでは，a-SiHの中で起こって いる局所的な環境をシミュレートするような原子 と電子の配置を作ることにする。具体的には，規 則的な構造の中に不規則性を導入したり，凍結法 によってアモルファス構造をコンピューターの中 に夷現したりして：ミクロな世界を探る。

次の三つのステップによって, SW 効果のミク 口な素過程を明らか心する゙务。

1.アモルファスのネットワークの中に, 確かに 弱い Si-Si ボンドが存在することを示す。

2. 弱い $\mathrm{Si}-\mathrm{Si}$ ボンドの近傍に水素が存在すると き，何が起きるかを示す。

3. Si-H ボンドを切るために必要なエネルギー とボンドのスイッチを和こすために必要な エネルギーを計算する。

これらの素過程の研究から, SW 効果のミク口 な機棈を提案することができる。

われわれのシミュレーションでは, 時間ステッ

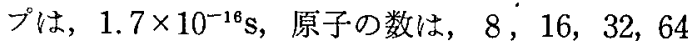
個，取り入れる平面波の数を決める最大エネルギ ーとしては13.5Ryを選んだ。また， Bachelet ら゙による norm-conserving な pseudopotentialを使った。

\section{4. a-SiHにおける原子と電子の構造}

\section{1 弱い $\mathrm{Si}-\mathrm{Si}$ ボンド}

第一原理 MD法によるシミュレーションから 得られた結果を解析して, a-SiHの中の弱い $\mathrm{Si}-$ $\mathrm{Si}$ ボンドの存在を示すことができた。搦い Si-Si ボンドの例として次のものが見つかった。

1.アモルファスなネットワークの中に幾何学的 な要請から生ずる弱い Si-Si ボンド。

2. $\mathrm{Si}-\mathrm{H}$ ボンドに隣接する $\mathrm{Si}-\mathrm{Si}$ ボンドは弱く なる傾问にある。

さらに，弱い Si-Si ボンドの二つの Si 原子は， 図 4 に示されるよらに，光学的な振動をしてお り，振動の中心の長さは，結晶シリコンにおける ボンドの長さより長い。本稿では, 特に断らない 限り，長さは結晶シリコンのボンドの長さ（2.35 丹）を単位にして測ることにする。成 4 の結果 は, Si-Si ボンドが比較的安定な形で存在し得る 


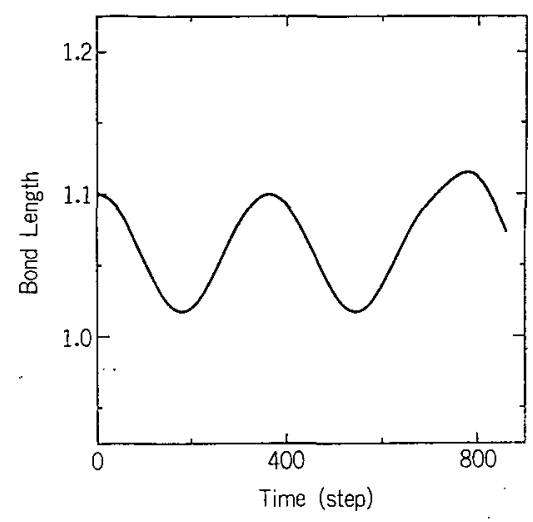

図 $4 \mathrm{Si-Si}$ ボンドの長さ vs 時間ステップ

ことを保証している。

第一原理 MDは原理的には基底状態にしか使克 なくて，励起状態に応用した場合には，電子のエ ネルギーレベルの精度が落ちる。しかし，原子構 造のお和よその様子を調べるだけなら，励起状態 も議論できることが知られている。これをふま克

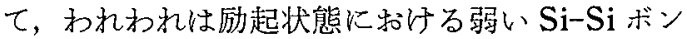
ドの振る舞いをMDで求めた。励起状態は，光照 射によって電子が励起された場合の状況をシミニ レートしている。励起状態では弱い Si-Si ボンド が長くなることが分施った。すなわか，光照射に よって，弱いSi-Si ボンドはさらに弱くなるので ある。

\section{2 弱い $\mathrm{Si}-\mathrm{Si}$ ボンドの近傍の水素原子}

弱い $\mathrm{Si}-\mathrm{Si}$ ボンドの近くにいる水素原子に関し ては次の結果が得られた。

いま注目している弱いSi-Si ボンドがあまり長 くない場合には，オフボンドの位置に水素の準安 定な場所があることが分かった。水素は，この位 置から比較的容易に拡散で流れ出すこともできる し，逆に拡散によってこの位置に比較的容易にも ぞってくることもできる。

一方，いま注目している弱いSi-Si ボンドがか なり長い場合には，一つの $\mathrm{Si}-\mathrm{H}$ ボンドと一つの ダングリング・ボンドが生成される。このミクロ な配置は室温では比較的安定で，高温では水素が 抎散で流れ出してしまう。

これらの結果は，次のよらな配置に対する系の 全エネルギーを計算することによって得られたも のである。
1. 水素が $\mathrm{Si}-\mathrm{Si}$ ボンド上にいる場合。

2. 水素が $\mathrm{Si}-\mathrm{Si}$ ボンドと垂值な直線上にいる場 合。

前者の結果は, 図 5 に与えられている。エネル ギーは Si-Si ボンドの中心からの距離（水素のい る場所）の関数として求められている。図中の百 分率は，注目している $\mathrm{Si}-\mathrm{Si}$ ボンドの長さを示 す。ただし，2.35Åを100\%としている。Si-Si の長さが $110 \%$ ときは, ボンドの中心が安定位 置である。Si-Si の長さが130\%になっても，ボン ドの中心が安定位置であることは变わらないが， 水素を中心からずらすために必要なエネルギーは

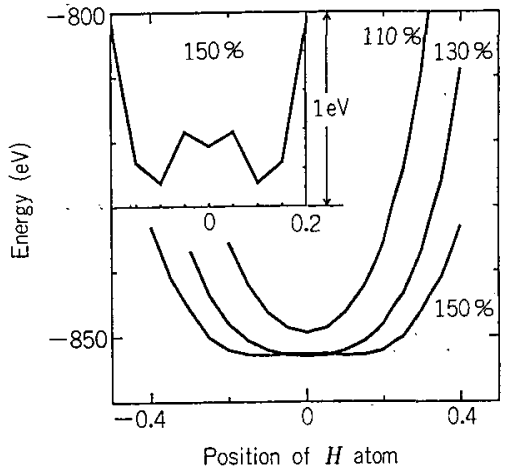

図 $5 \mathrm{Si}-\mathrm{Si}$ ボンド上に水素原子がある配㯰の 全エネ ルギー。水素原子の位盍はボンドのセンターか ら規格化された長さによって測られている。図 中の百分率は Si-Si ボンドの長さを表している

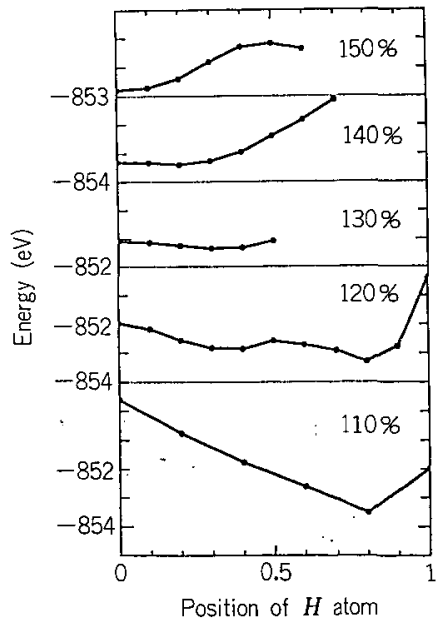

图 $6 \mathrm{Si}-\mathrm{Si}$ ボンドに直角な直線上に水素原子がある 場合の配固の全エネルギー。水素原子の位置は ボンドのセンターから规格化された長さによっ て測られている。図中の百分率は Si-Si ボンド の長さを表している 
非常に高くなる。Si-Si の長さが150\%になると, ボンドに沿って, 二つの極小点が現れる。

後者の結果は, 図 6 に与光られている。エネル ギーは Si-Si ボンドの中心から，ボンドに垂直な 方向へ距離（水素のいる場所）の関数として求め られている。図中の百分率は，注目している $\mathrm{Si}-$ $\mathrm{Si}$ ボンドの長さを示す。

$\mathrm{Si}-\mathrm{Si}$ の長さが110\%のときは, ボンドの近くに 安定な位置はない。Si-Si の長さが120\%から140 \%の場合には, オフボンドの場所に水素の安定位 置が存在する。

\section{3 電子密度の等高線}

前小節で説明した状況は，電子密度の等高線を 見ることによって，より明らかに把握することが できる。比較のためにまず, 結晶シリコン中の $\mathrm{Si}$ ネットワークに沿っての等高線を図7(口絵 1)に 示す。この図で，電子密度の高さは，赤，黄色，

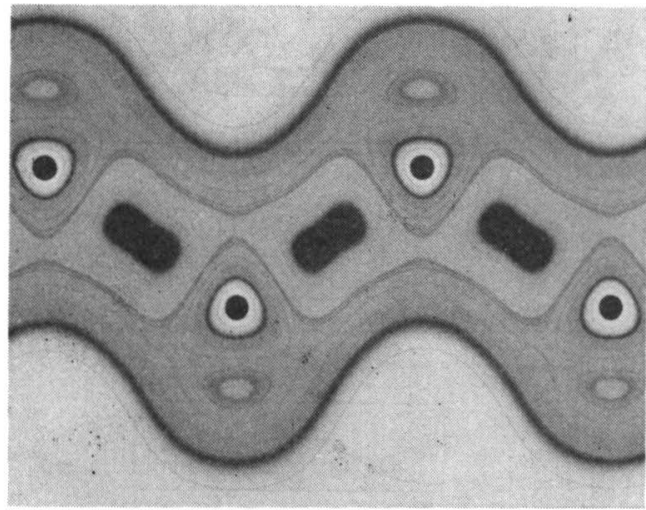

图7 結晶シリコン中のシリコン原子のボンドに沿った電 子密度の等高線

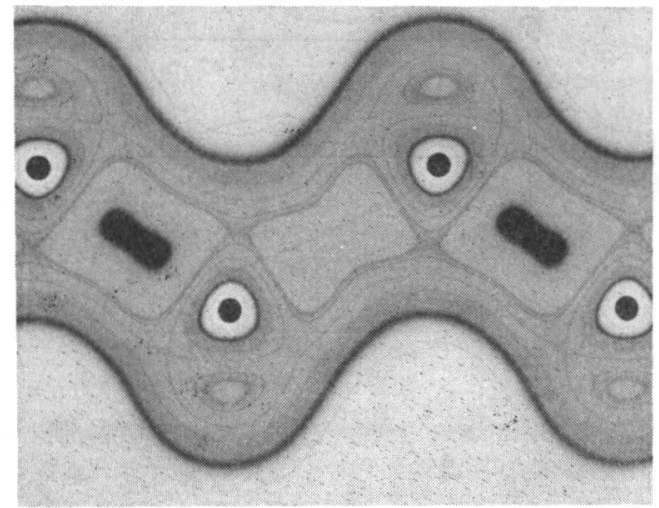

图 $8 \mathrm{Si}-\mathrm{Si}$ ボンドが結晶シリコンの場合に比べて $110 \%$ 伸びた場合の電子密度の等高線
緑，青，白の順に低くなっている。黒い丸は Si 原子を表す。

図 8 (口絵 2) には，弱い Si-Si ボンドに対する 等高線が描かれている。図からも明らかなように, ボンドが「弱い」といらのは，ボンドの長さが長 いという意味だけでなく，ボンドの結合軌道上の 電子密度が低いことも意味しているのである。

また，Si-H ボンドに隣接した $\mathrm{Si}-\mathrm{Si}$ ボンドは 弱いことも確かめられる。図 9(口絵 3) には, H$\mathrm{Si}-\mathrm{Si}-\mathrm{Si}$ ボンドに沿った等高線が描かれている。 水素の電気陰性度の高さを反映して水素原子の近 傍の電子密度は高く，したがって Si-H ボンドに 隣接する $\mathrm{Si}-\mathrm{Si}$ ボンドは弱くなっている。この $\mathrm{Si}-\mathrm{Si}$ ボンドは, 長さが長いという意味でも, ボ ンドの上の電子密度が低いという意味でも, 弱い ことが分かる。

図10（口絵 4）には，オフボンドの準安定配置 に対する等高線が描かれている。電子は，注目す

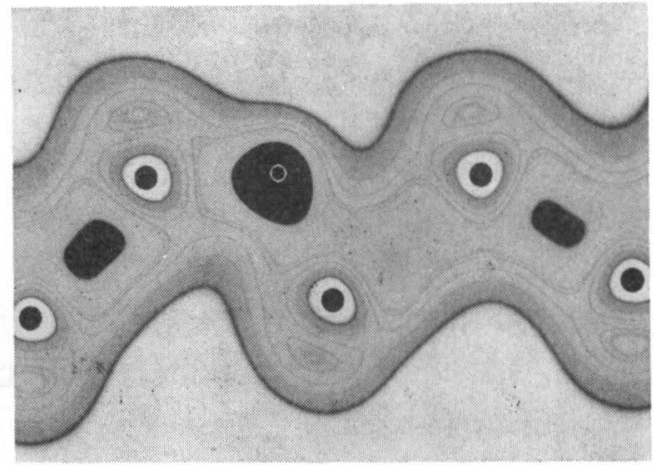

図 $9 \mathrm{Si}-\mathrm{Si}$ ボンドに直角な直線上, $40 \%$ の位置に水素原 子がある場合の電子密度の等高線

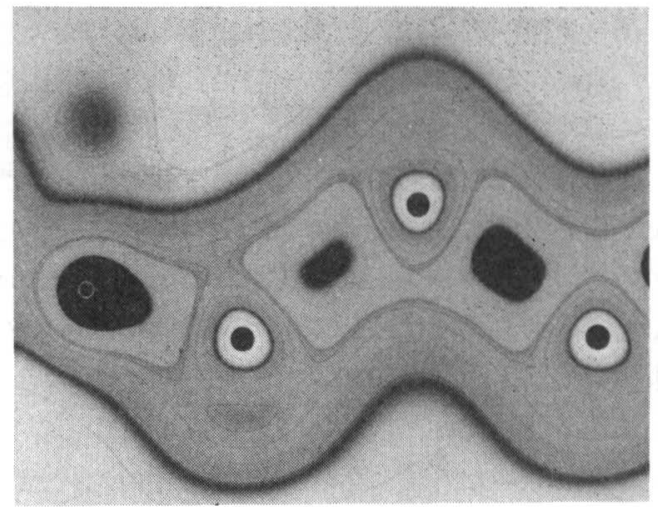

図10 Si-Si-Si-H ポンドに沿った電子密度の等高線 
る二つのSi原子に共有される形になって拈り、こ れがェネルギーを下げる原因になっている。

上述の三つのステップを調べることによって,

SW 効果のミクロな素過程の機構が明らかになっ た。具体的には，フォトンによって Si-H ボンド の水素が, 隣接の弱いSi-Si ボンドのオフボンド 準安定位置にスイッチし，元の $\mathrm{Si}-\mathrm{H}$ の位置にダ ングリング・ボンドが生成される。水素原子はボ ソドに沿ってつぎつぎにスイッチをし，Si-Siが 比較的長いところで, $\mathrm{Si}-\mathrm{H}$ ボンドとダングリン グ・ボンドが生成されてスイッチは終る。この一 連のスイッチによって，二つのダングリング・ボ ンドが作られることになる。

\section{5. おわりに}

第 2 節で紹介したわれわれの映画「ガラス転 移」は，1989年に科学技術庁長官賞を受賞しまし た。この映画は，16mmフィルム，および，ビデ オの形にまとめられて招り，興味のある方には， 実費で抄けしています。
第一原理分子動力学の研究は, 文部省科学研究 費, 重点領域研究, 「計算物理学——物性研究に おける新展開」の一環として行われました。

$$
\text { 文献 }
$$

1) F. Yonezawa: in "Solid State Physics", vol. 45 ( $\mathrm{H}$. Ehrenreich and D. Turnbull, eds.), Academic Press, 1991.

2) M. Kimura and F. Yonezawa: in "Topological Disorder in Condensed Matter" (F. Yonezawa, ed.), Springer, 1983.

3) F. Yonezawa, S. Nosé and S. Sakamoto: Neue Folge 156, 77(1988).

4) R. Car and M. Parrinello: Phys. Rev. Lett. 552471 (1985).

5) D. L. Staebler and C. R. Wronski: Appl. Phys. Lett. 31292 (1977).

6) F. Yonezawa, S. Sakamoto, and M. Hori: Invited Talk at "14th International Conference on Amorphous Semiconductors (ICAS14)": To be published in the proceedings of ICASI4 as a special issue of J. Non-Cryst. Solids (1991).

7) S. Sakamoto and F. Yonezawa: Submitted to Phys. Rev. (1991). 


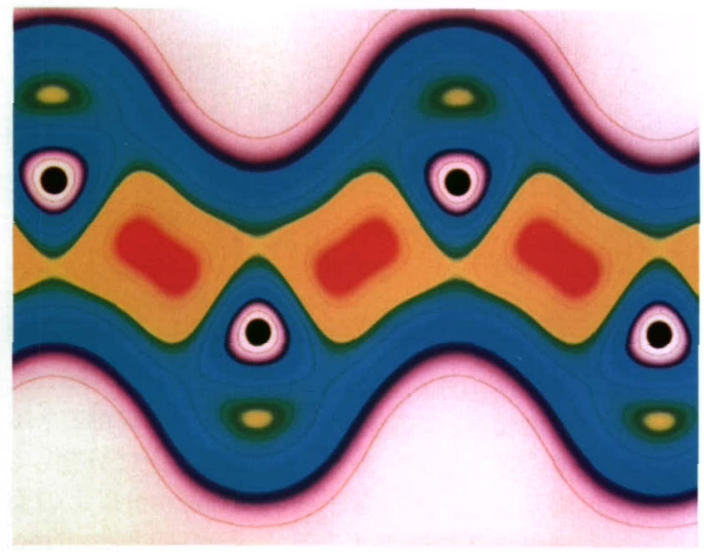

ロ絵1 結晶シリコン中のシリコン原子のボンドに沿った 電子密度の等高線

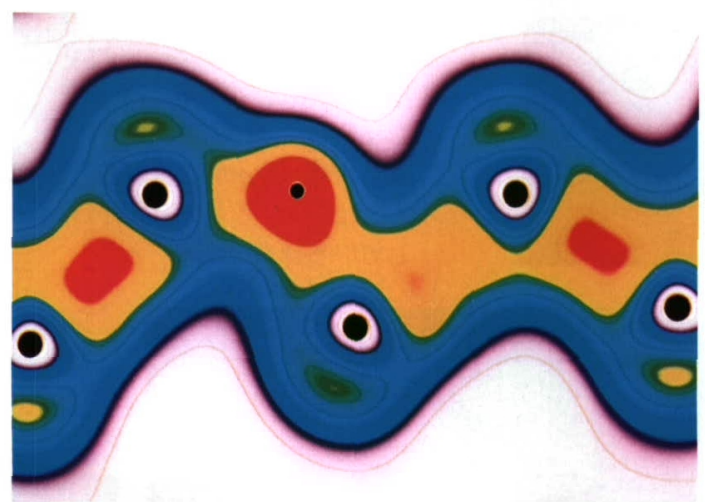

口絵 $3 \mathrm{Si}-\mathrm{Si}$ ボンドに直角な直線上, $40 \%$ の位置に水 素原子がある

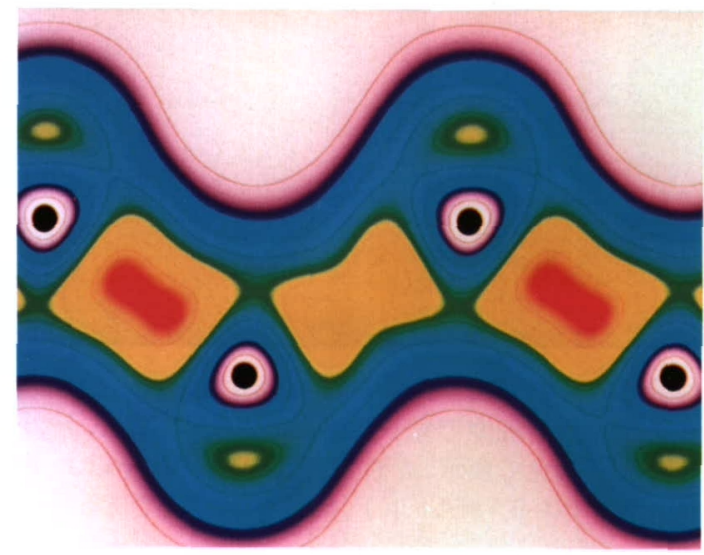

口絵 2 Si-Siボンドが結晶シリコンの場合に比べて110 \%伸びた場合の電子密度の等高線

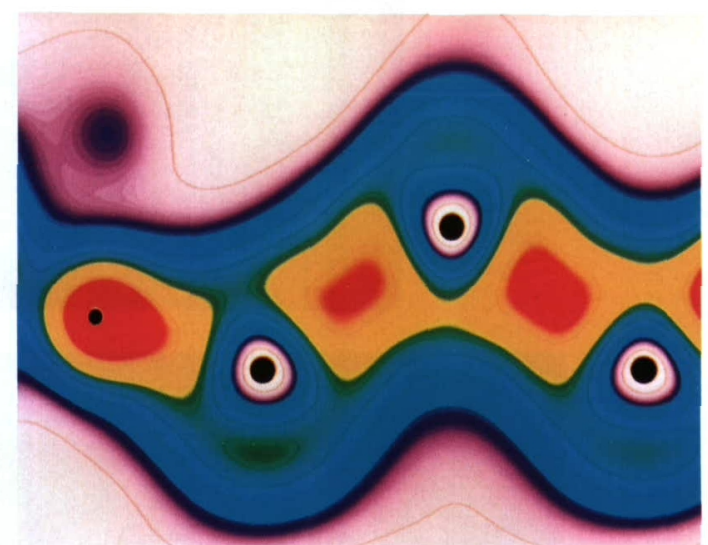

口絵4 Si-Si-Si-Hボンドに沿った電子密度の等高線

(本文 9 頁参照)

$\left(\begin{array}{ll}\text { 慶応義塾大学 米沢富美子 } \\ \text { 成 } \text { 蹊 大学 坂本 昇一 }\end{array}\right)$ 